\title{
Affective damage from teachers' written corrective feedback
}

\author{
Gartika Pandu Bhuana*, Ula Nisa E1 Fauziah \\ English Education Study Program, The Faculty of Language Education, IKIP Siliwangi, \\ Cimahi, Indonesia \\ *Corresponding Author \\ Email: gartika@ikipsiliwangi.ac.id
}

Received:

14 December 2020
Revised:

2 July 2021
Accepted:

20 August 2021
Published:

31 August 2021

\begin{abstract}
Several studies believe that providing feedback on a students' writing task offers several benefits. However, giving excessive corrections on students' mistakes can have a negative impact on the students' feeling. This study aims to investigate English Foreign Language students' emotional response to the teachers' written corrective feedback. A qualitative method was applied. The participants were 72 third grade students at an institution in Cimahi. To collect the data, a five-point Likert scale questionnaire and a semi-structured interview were applied. The results revealed that the teachers' written corrective feedback had negative impact to the students' feelings, especially for the students who had mid and low proficiency level in writing. It even led to the students' demotivation. This indicates that the teachers have to consider several things before they give some written feedback as it can affect the students' attitude in a negative way.
\end{abstract}

Keywords: teacher's written corrective feedback; students' emotional response

\section{INTRODUCTION}

How teachers correct second language students' writing has become an interested topic to be discussed. The controversy of its usage has made its own challenge. The debate between Ferris and Truscott in 1990s is a basis for many studies to investigate deeply the use of written corrective feedback (WCF) for second language students.

Written corrective feedback is basically the teachers' method to correct the students' errors production in writing (Ellis, 2009) in order to provide a guidance for them to rewrite their writing. Written corrective feedback can take many different forms. However, two overly discussed types are direct and indirect corrective feedback. The first type of feedback focuses on the provision of the correct form of students' errors (Bitchener et al., 2005; Hyland \& Hyland, 2006; Domakani \& Roohani, 2010; Irwin, 2017; Goksoy \& Nazli, 2016; Westmacott, 2017). In this type of feedback, the teachers identify the error, clarifies the ideas, and provides the correct form. This feedback has an additional form known as metalinguistic feedback, in which the teachers 
provide some comments or information related to the errors (Ellis, 2009). The last type is indirect corrective feedback, in which the teachers do not provide any correction, instead they mark the errors and let the students do selfcorrection (Goksoy \& Nazli, 2016; Westmacott, 2017; Ellis, 2009; Hyland \& Hyland, 2006). This feedback is categorized into coded and un-coded. In coded feedback, the students errors is indicated by symbols predetermined in the classroom, while in un-coded feedback, the students' error is just simply marking without any code, sign, or symbol (Ellis, 2009; Goksoy \& Nazli, 2016; Westmacott, 2017; Hyland \& Hyland, 2006). Corrective feedback can be begun in the revising stages (Saukah et al., 2017), when the draft of students writing has already been produced (Giri, 2018).

Many teachers and researchers (e.g. Bitchener \& Knoch, 2009; Pourdana et al., 2021) believe that written corrective feedback facilitate the students to master the second language linguistic form and structure. It can also improve the students' writing accuracy (Ferris, 1999). The application of written feedback leads students to become more aware to their error. They will know their weaknesses and strengths as there is a readers' judgement of their text (Hyland, 2013; Carles, 2006). It can also modify the students' mind set and attitude toward their work, and force them to focus on the purpose of writing (Saukah et al., 2017). As a result, it can promote an improvement on their second language acquisition (Li, 2010; Ellis, 2010; Lyster \& Saito, 2010). However, Brown (2007), advice the teachers to carefully consider the method of responding to and correcting the students' writing.

Even though many studies has shown the positive impact of written corrective feedback, Truscott (2007) argues that any form of correction is not effective. It cannot reduce the frequency of the students' error and negatively impact to the students' ability to write for communicative purposes (Truscott, 1996; Irwin, 2017). It is even harmful (Farrokhi et al., 2018) as the teachers tend to be careless and insensitive with their comments (Irwin, 2019). Thus, it can affect the students' affective factor which have been largely ignored by many studies (Mahfoodh, 2017; Goetz et al., 2018; Harris et al., 2014; Goo \& Takeuchi, 2021).

The need of examining second language the students' emotional response toward the teachers' written corrective feedback has been highlighted by many experts (e.g. Mahfoodh, 2017; Dowden et al., 2013). This is because the success of language learning depends not only on the students' cognitive ability, but also on the students' emotional response. As Swain (2013) argues that cognition and emotion are totally integrated. Emotion provides a great contribution for learning as it affects the students' success, motivation, and satisfaction (Sarsar, 2017). In other words, the more emotionally engaged the students are, the more likely they will learn. It can also give a clue for the teachers about classroom condition and environment during the instruction (Sarsar, 2017).

This study intends to investigate the students' emotional response to the written corrective feedback given by the teachers. In this study, the students are classified into three categories of proficiency: low-proficiency level, midproficiency level, and high- proficiency level. This is because the students at each proficiency levels might have different responses to the written corrective feedback provided by the teachers. 


\section{METHOD}

A qualitative method was employed. This method was chosen as the ability to triangulate the data. It allowed the combination of multiple source of data in analysis in order to develop full understanding of a phenomenon (Carter et al., 2014). It also helped to gain the insight into specific behaviour in certain context through subjective experience of the participants (Palmer \& Bolderston, 2006)

Seventy-two students of an English Education Program at one of institution in Cimahi were partaken in this study as the participants. They were in the third semester and they ever took the Writing for General Communication course and Writing for Professional Context course. In these two courses, the teachers used the online learning management system, such as Google Classroom, Schoology or Edmodo to share the material. The teachers also instructed the student to submit their assignment on those elearning platforms, then they provided feedback.

Concerning proficiency levels, 16 of 72 students were categorized as high-achievers, 36 students as mid-achievers, and 20 students as lowachievers. The students' proficiency levels were gained from the students' writing test that was assessed by the teachers by using Anderson's analytical scoring rubric. There were five components of writing that were assessed: grammar, vocabulary, mechanics, fluency, and form (Hughes, 2003).

To collect the data, the questionnaire and interview were utilized. The questionnaire used five-points Likert Scale that was ranged from strongly disagree, disagree, neutral, agree, and strongly agree. This type of questionnaire was applied to examine one's attitude toward a person or group, event, or social phenomena based the statement that have been set by the researcher (Joshi et al., 2015). In this study, the questionnaire consisted of 12 questions which were divided into 3 sub-topics: 1) general information of the written corrective feedback, such as the types of corrective feedback used and the frequency of teachers' corrective feedback; 2) students' general opinion to the use of written corrective feedback; and 3) students' response. This questionnaire was adapted from Martinez (2014). Moreover, the interview was semi-structured and consisted of 5 main questions. The interview was used to uncover the story behind the students' experience of getting written corrective feedback, or to further investigate students' response in the questionnaire. In other words, it was used as an additional instrument to support the data gained from the questionnaire.

The result of the questionnaire and the interview was firstly categorized by the students' proficiency levels. The questionnaire was calculated, while the interview was transcribed. They were then analysed by using several theories related to the study.

\section{RESULTS AND DISCUSSION}

This study aims to find out the students' emotional response to the written corrective feedback. The results were classified into three parts, based on the students' proficiency levels. There were 16 students categorized as highachievers. Most of them have already known how to arrange the idea into good 
Bhuana, G. P., \& El Fauziah, U. N. (2021). Affective damage from teachers' written corrective feedback. EduLite: Journal of English Education, Literature, and Culture, 6 (2), 287-299. http://dx.doi.org/10.30659/e.6.2.287-299

paragraph and writing. They also had good vocabularies, and could use punctuation correctly. They only made a few mistakes in grammar.

There were also 36 students classified as mid-achievers. These students have already known how to transfer their idea into written words. Unfortunately, they still lack of grammatical mastery. Most of them also made mistakes in singular or plural or subject and verb agreement. They also produced some mistakes in punctuation, especially in the use of comma.

Furthermore, there were 20 students categorized as low-achievers. Alike mid-achievers, most of low-achievement students showed problems in grammar, such as plural and singular, tense, subject and verb agreement, or word formation. They also made many mistakes in using punctuation and capitalization. Some of them also lack vocabulary in English. This could be seen from the variety of words they used in their writing test.

\section{The high-proficiency students}

The questionnaire results show that the teachers used indirect corrective feedback in giving the signal of the students' mistakes. They mostly used uncoded feedback in which they just circled the mistake. In the frequency point, the teachers just provided a few corrective feedbacks. In this case, they more focused on correcting the students' grammatical and mechanical mistake. This finding supported the data gained from the interview. On the interview, the students said that the teachers just circled their mistake without providing the detail explanation of their mistake. They also said that the teachers more focused on grammar and mechanic, instead of content or organization of their writing. Regarding the students' emotional response to the use of written corrective feedback, it is showed in Figure 1.

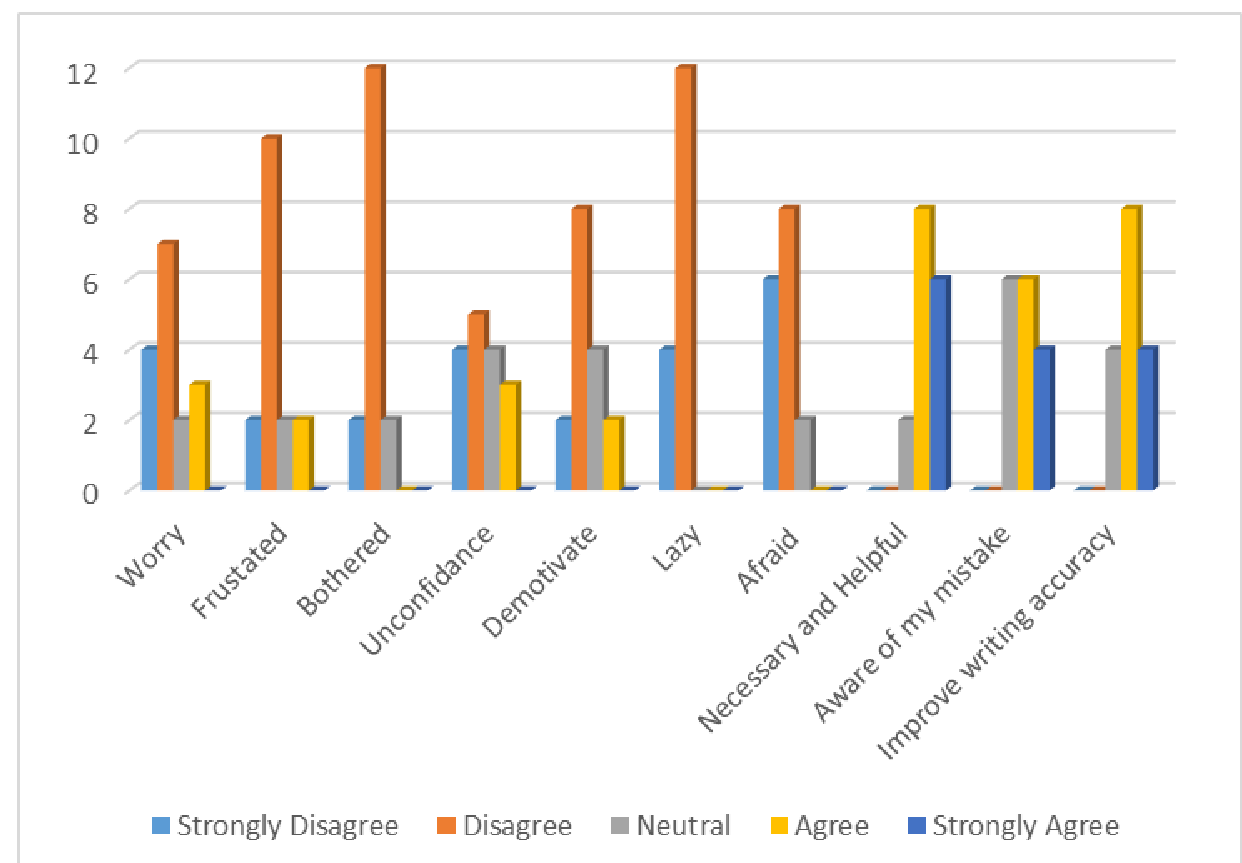

Figure 1. The high-proficiency students' emotional response to the use of teachers' written corrective feedback 
Figure 1 shows that most of the high-proficiency students (69\%) felt unworried of getting a lot of corrections from the teachers. Most of them $(87 \%)$ also did not feel frustrated and bothered to the correction given. They (56\%) thought that the teachers' correction could not decrease their confidence to write. Instead, they (87\%) were encouraged to re-read the material and revise their writing. They were sure that they would get a good score after conducting a revision. They (87\%) were also not afraid if their revised paper got the correction from the teachers. In addition, most of them had a good opinion to the implementation of teachers' corrective feedback. They $(87 \%)$ thought that the teachers' written corrective feedback was beneficial. They (62\%) believed that it could assist them to be aware of their errors in writing. Most of them (75\%) even assumed that it also helped them to improve their writing quality. The interview data also depicted that they tried to be careful in using grammar while they were writing. They also considered the use of punctuation carefully.

The above results indicate that most of the high-proficiency students had positive affective attitude to the implementation of the teachers' written corrective feedback. This was supported by the calculation of the Likert-Scale questionnaire.

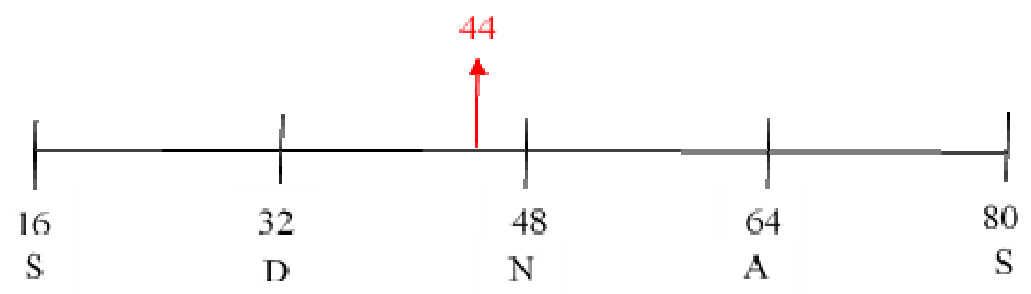

Figure 2: The score of likert-scale questionnaire answered by the high-proficiency students

The calculation shows that the average score of the students' answers was 44 . This was in the range of disagree to neutral. This means that the students who were at high proficiency level felt no emotional impact to the use of teachers' feedback. On the interview, one of the students even thought that the written corrective feedback tended to offer more advantages than the drawbacks.

S1 I do not feel it demotivates me to do revision. I also do not feel frustrated when I have to correct my mistakes.

S2 No, I think the advantages is quite bigger than the disadvantages. At first, yes, I am worried of making mistake in my writing. Now, it seems that I am enthusiastic to read the teachers' comment or feedback.

S3 No, it does not give any impact for me. 
Bhuana, G. P., \& El Fauziah, U. N. (2021). Affective damage from teachers' written corrective feedback. EduLite: Journal of English Education, Literature, and Culture, 6 (2), 287-299. http://dx.doi.org/10.30659/e.6.2.287-299

\section{The mid-proficiency students}

The data reveal that the teachers mostly used coded and un-coded corrective feedback to correct the students' work. In coded corrective feedback, the teachers used the sign, such as S.V for subject and verb agreement; and PI/SI for plural or singular error; $\mathrm{C}$ for capitalization mistake; $\mathrm{M}-\mathrm{C}$ for the error in mechanics such as comma. Meanwhile, in un-coded corrective feedback, the teachers just circled the students' mistake. This finding was in line with the data gained from the interview. One of the students said that the teachers mostly used circle to indicate the mistake in their writing. The other said that the teachers just gave a signal of their mistake.

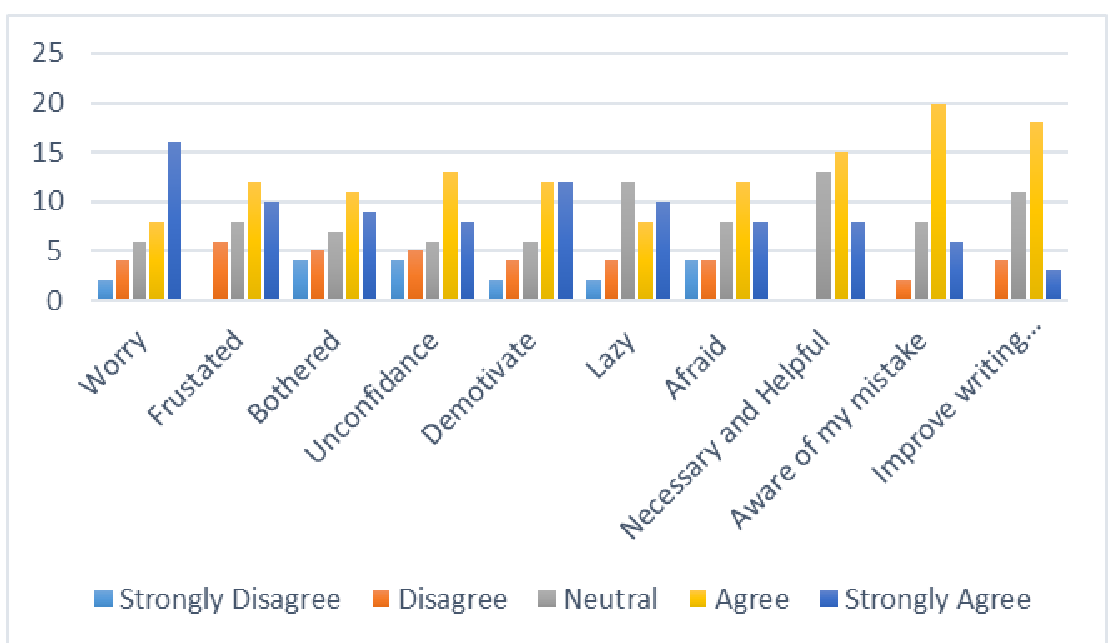

Figure 3. The mid-proficiency students' emotional response to the use of teachers' written corrective feedback

Figure 3 portrays the students' emotional response to the use of corrective feedback. Dissimilar to the high-proficiency students, most of the mid-achievers (67\%) said that the teachers' corrective feedback made them worried of producing errors in their writing. Half of them $(61 \%)$ felt frustrated after they got the correction from the teachers. They (55\%) even felt bothered to the amount of corrective given by the teachers. They $(58 \%)$ also felt unconfident to their ability in writing an English text. As a result, some of them $(58 \%)$ were demotivated to write. They $(50 \%)$ were also lazy to revise their writing. This was because they (56\%) were afraid of getting another correction on their paper. Even though they had negative response to the use of teachers' corrective feedback, most of them (64\%) believed that the teachers' written corrective feedback had some advantages. Through the correction given by the teachers, they $(72 \%)$ became aware of their mistake. They were also prompted to find out more about their errors writing. The interview data reveal that they did some efforts to revise the errors in their writing, such as re-read the material given by the teacher or asked a help from their friend to review their revised paper. Consequently, their writing accuracy was improved well.

The above result implies that the mid-proficiency students had negative emotional impact to the teachers' corrective feedback. This was in line with the results of the Likert-Scale calculation. The result shows that the total score of the students' answers in the questionnaire was 72 , which was in the category 
of neutral to agree. In other words, the mid-proficiency students felt the negative impact of the teachers' correction on their emotional aspect.

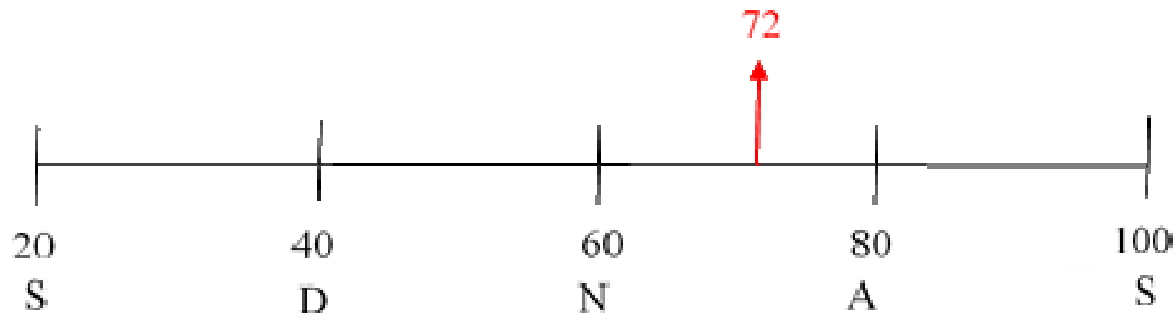

Figure 4: The score of Likert-scale questionnaire answered by the mid-proficiency students

The above findings corroborated the interview result. Two of three students said that they felt the emotional impact of the teachers' written corrective feedback. One of them even admitted that he felt unconfident. He worried of becoming the one who got a lot of corrections from the teachers.

S4 I am not sure because when I get correction in my paper, I feel that I have to work hard to not make the same mistake.

S5 Yes, especially when it gives on the feed. I am afraid everybody will see it. I feel shamed if I become the one who get a lot of corrections in writing assignment.

S6 Hmm sometimes I feel upset when I see a lot of corrections in my paper. But, it never demotivates me to learn.

\section{The low-proficiency students}

Similar to the mid-achiever, the teachers corrected the students' error production by using both coded and un-coded corrective feedback. The teachers almost corrected every single mistake that was produced by the students. The correction focused on the verb tense agreement, word formation, singular and plural, or subject and verb agreement, or mechanic. On the interview, one of the students said that he felt confused when he saw his paper corrected by the teachers. The teachers never left a single error that he made. Related to the students' emotional response to the use of corrective feedback, it is presented in Figure 5. 
Bhuana, G. P., \& El Fauziah, U. N. (2021). Affective damage from teachers' written corrective feedback. EduLite: Journal of English Education, Literature, and Culture, 6 (2), 287-299.

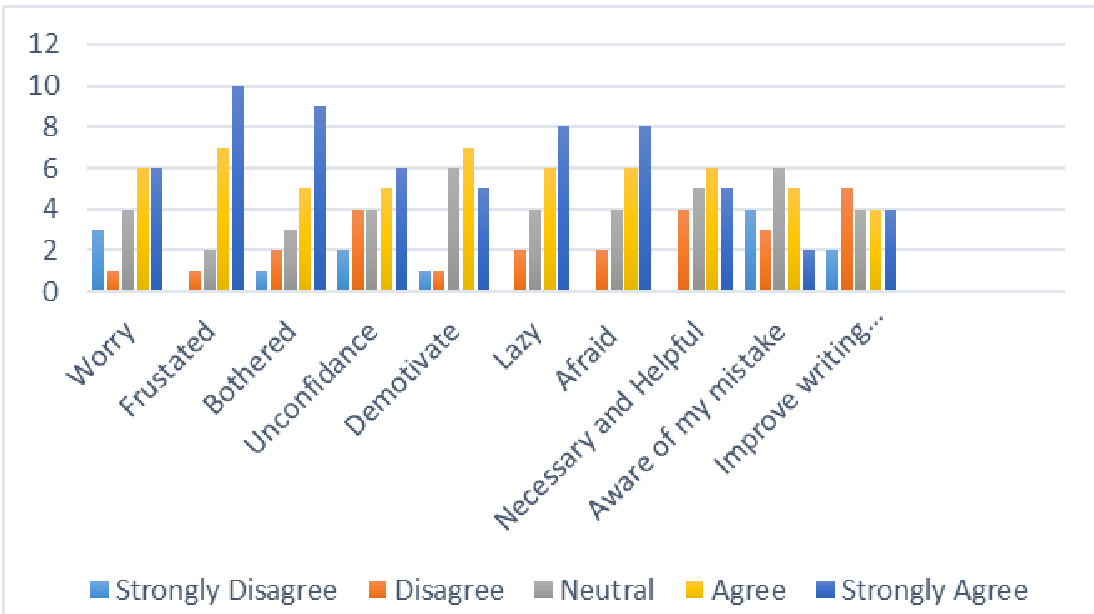

Figure 5. The low-proficiency students' emotional response to the use of teachers' written corrective feedback

The result of questionnaire reveals that most of the low-proficiency students $(60 \%)$ felt worried of making error production in their essay. They $(85 \%)$ felt frustrated while there were so many corrections in their essay. They $(70 \%)$ also felt bothered to the way the teachers corrected the mistake. Consequently, some of them (55\%) were unconfident and demotivated to write. They $(70 \%)$ were also lazy and afraid to do a revision. This was because they did not know what they should do. On the interview, it was found out that the students got confusion when the teachers only circled their error without giving any information. Then, only some of them (55\%) who believed on the benefits of teachers' correction. Few of them (35\%) thought that the teachers' feedback could help them to be aware of their mistake in writing. The other were uncertain. Moreover, only 40\% students who admitted the impact of teachers' correction on the improvement of their writing accuracy. Other students $(20 \%)$ were unsure about it, and the other $(40 \%)$ were disagree.

The above data imply that most of the students at low proficiency level felt that written corrective feedback damaged their affective aspect. This was in line with the result of Likert-scale analysis. The calculation result was on 74 . This score was in the range of neutral to agree. Hence, it can be concluded that the implementation of the teachers' written corrective feedback was harmful for low-achievers.

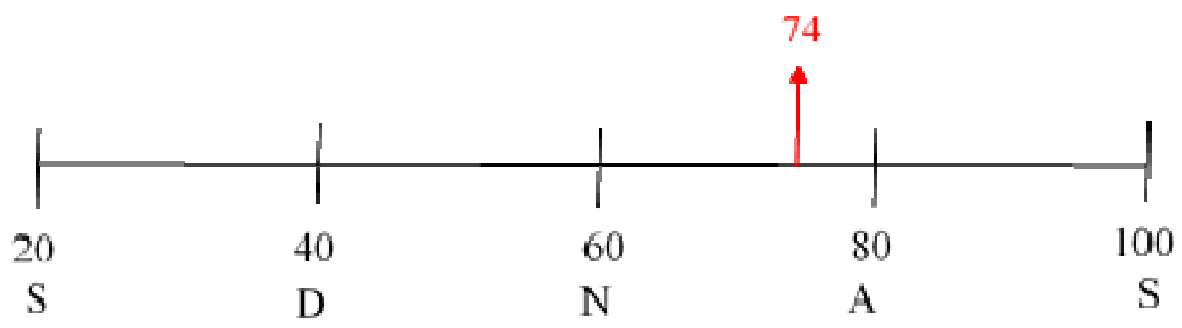

Figure 6: The score of Likert-scale questionnaire answered by the low- proficiency students 
The findings were in accordance with the data gained from the interview. All of the students felt frustrated to revise their paper after they got the correction from the teachers. One of them even admitted that she sometimes asked their friend to help her in revising the paper.

S7 Honestly, every time I get my paper back, I feel so lazy to revise it. I cannot understand what is highlighted by the teacher.

S8 I feel lazy to check the paper that is being corrected by the teacher. I do not know what I have to do. I sometimes ask my friend to identify every clue given by the teachers.

S9 If I can choose, I do not want to revise my paper. It makes me frustrated.

In short, most of participants, particularly the high- and mid- proficiency students, recognize the need and advantageousness of corrective feedback. It can not only increase their writing accuracy (Ferris, 1999; Farjadnasab \& Khodashenas, 2017) or quality (Taufiqulloh et al., 2016), but also elevate the their awareness of their errors. It pushes them to find out more of their errors (Hyland, 2013; Wibowo, 2018). It also develops their critical thinking and motivation. This implies that written corrective feedback is necessary in developing the students' language writing competence (Martinez, 2014) and in improving their second language acquisition (Lyster \& Saito, 2010; Li, 2010; Ellis, 2010).

Unfortunately, some factors are contributed to the success or failure of the teachers' written corrective feedback (Flaherty, 2016; Irwin, 2017). One of them is the students' attitude (Irwin, 2017), including their affective factor. The results of the study reveal that written corrective feedback used by the teachers had different emotional impact to the students at each level of proficiency. The high-proficiency students, for example, had positive emotional response to the implementation of written corrective feedback. In contrast, the mid and low- proficiency students had negative response.

The different of students' response here is probably caused by types of feedback given by the teachers. The results show that the teachers dominantly used indirect corrective feedback both coded and un-coded type. This kind of feedback demands the students to have a good grammatical knowledge as they have to identify the meaning of the signal given by the teachers and do selfcorrection. The use of this feedback to the high-proficiency students might be appropriate. Kennedy (2010) says that this kind of students has more linguistic resources to call on. Therefore, when the teachers give indirect corrective feedback and the opportunity to do self-correction, they easily use those resources to revise the errors (Kennedy, 2010). On the other hand, the mid and low-proficiency students have limited grammatical knowledge. The feedback without the corrected form, such as un-coded corrective feedback, will be confusing and burdensome for them (Ahangari \& Amirzadeh, 2011; Kennedy, 2010) as they cannot identify and repair their written errors. As a result, they will feel frustrated when they get a lot of corrections in their writing assignment. 
Bhuana, G. P., \& El Fauziah, U. N. (2021). Affective damage from teachers' written corrective feedback. EduLite: Journal of English Education, Literature, and Culture, 6 (2), 287-299.

http://dx.doi.org/10.30659/e.6.2.287-299

Correcting the students' written error is important. It can avoid fossilization. However, it should be done in appropriate way. The teachers should recognize the exact time and way to correct the error. In this case, the teachers are suggested to use different types of corrective feedback for the mid and low proficiency students. They can use direct or metalinguistic feedback as it provides the correct form or explanation of the students' errors. While the teachers are correcting the students' written errors, they are also suggested to focus on correcting the errors that are related to materials that are learned by the students. They do not need to correct every single mistake of the students' errors as providing the correction on large number of error may overwhelm the students (Jayathilake, 2013; Storch, 2010).

Furthermore, the teachers also should consider the students' sensitiveness. Corrective feedback, either written or oral, are reciprocally linked to emotions (Goetz et al., 2018). It can directly or indirectly elicit strong emotion which in turn have an impact on the subsequent students' learning behaviour and learning outcome (Goetz et al., 2018). In other words, positive emotion such as happy and interested may lead to positive behaviour in learning, by which the students are motivated to learn. As Wibowo (2018) notes that when the students feel happy or get an expected stimuli, it can raise their willingness and enthusiasm to learn and join the instruction. In contrast, negative emotion, such as fear, irritation or frustration, shame, embarrassment, will demotivate them to learn (Martinez, 2014).

\section{CONCLUSION}

Corrective feedback is needed to inform the students of their error. It also requires to avoid fossilization of the error. Nevertheless, its implementation should consider several factors. One of them is students' affective aspect. Students' affective aspect is related to the students' emotional response toward something, which is in this study is toward teachers' written corrective feedback. The results show that teachers' correction damages students' affective aspect, specifically for those who have mid and low proficiency in writing. Most of them feel not only frustrated, but also unconfident. It also demotivates them to write. Therefore, the teachers are expected to be more careful in correcting the students' writing. They have to consider the students' feeling. Giving to much correction in their writing can give a bad impact on their feeling as well as their motivation in learning. Regarding this, the teachers have to determine the appropriate type of feedback that need to be given to the students. They can also focus on correcting the mistake that is related to the material learned. Thus, it cannot burden the students to much; and may create positive response from them which in turn lead to positive behaviour in learning.

\section{ACKNOWLEDGEMENTS}

The researchers would like to thank the students for their participation in filling out the questionnaire and interview. We also like to acknowledge the lecturers of English Education Study Program who planned writing lesson by 
Edulite Journal of English Education, Literature, and Culture

Vol. 6, No. 2, August 2021, pp. 287-299

E-ISSN: 2528-4479, P-ISSN: 2477-5304

http://jurnal.unissula.ac.id/index.php/edulite DOI: http://dx.doi.org/10.30659/e.6.2.287-299

using learning management system, such as Google Classroom, Schoology, or Edmodo.

\section{REFERENCES}

Ahangari, S., \& Amirzadeh, S. (2011). Exploring the teachers' use of spoken corrective feedback in teaching Iranian EFL learners at different levels of proficiency. Procedia - Social and Behavioral Sciences, 29(2010), 1859-1868. https://doi.org/10.1016/j.sbspro.2011.11.435

Bitchener, J., \& Knoch, U. (2009). The value of a focused approach to written corrective feedback. ELT Journal, 63(3), 204-211. https://doi.org/10.1093/elt/ccn043

Bitchener, J., Young, S., \& Cameron, D. (2005). The effect of different types of corrective feedback on ESL student writing. Journal of Second Language Writing, 14(3), 191-205. https://doi.org/10.1016/j.jslw.2005.08.001

Carter, N., Bryant-Lukosius, D., DiCenso, A., Blythe, J., \& Neville, A. J. (2014). The use of triangulation in qualitative research. Oncology Nursing Forum, 41(5), 545547. https://doi.org/10.1188/14.ONF.545-547

Dowden, T., Pittaway, S., Yost, H., \& McCarthy, R. (2013). Students' perceptions of written feedback in teacher education: Ideally feedback is a continuing two-way communication that encourages progress. Assessment and Evaluation in Higher Education, 38(3), 349-362. https://doi.org/10.1080/02602938.2011.632676

Ellis, R. (2009). A typology of written corrective feedback types. ELT Journal, 63(2), 97107. https://doi.org/10.1093/elt/ccn023

Ellis, R. (2010). Epilogue: A framework for investigating oral and written corrective feedback. Studies in Second Language Acquisition, 32(2), 335-349. https://doi.org/10.1017/S0272263109990544

Farjadnasab, A. H., \& Khodashenas, M. R. (2017). The effect of written corrective feedback on EFL students' writing accuracy. International Journal of Reserach in English Education, 30-42. https://doi.org/10.23971/jefl.v6i2.401

Farrokhi, F., Zohrabi. M., \& Mohammad, Azad, H. C. A. (2018). Corrective feedback and Iranian EFL learners' spoken complexity and accuracy. Teaching English Language, 12(2), 117-143. https://doi.org/10.22132/tel.2018.76934

Ferris, D. (1999). The case for grammar correction in L2 writing classes: a response to Truscott (1996). Journal of Second Language Writing, 8(1), 1-11. https://doi.org/10.1016/S1060-3743(99)80110-6

Flaherty, D. O. (2016). Japanese high school students ' attitudes towards and usage of corrective feedback on their written work. The Language Teacher 40.6. https://doi.org/10.37546/JALTTLT40.6-1

Giri, R. A. (2018). CAF: a collaborative approach to providing feedback. Indonesian JELT: Indonesian Journal of English Language Teaching, 13(2), 85-114. https://doi.org/10.25170/ijelt.v13i2.1452

Goetz, T., Lipnevich, A. A., Krannich, M., \& Gogol, K. (2018). Performance feedback and emotions. In A. A. Lipnevich \& J. K. Smith (Eds.), The Cambridge Handbook of Instructional Feedback (pp. 554-574). Cambridge University Press. https://doi.org/10.1017/9781316832134.027

Goksoy, A. S., \& Nazli, Ö. P. (2016). The effect of direct and indirect written corrective 
Bhuana, G. P., \& E1 Fauziah, U. N. (2021). Affective damage from teachers' written corrective feedback. EduLite: Journal of English Education, Literature, and Culture, 6 (2), 287-299. http://dx.doi.org/10.30659/e.6.2.287-299

feedback on grammatical collocations in L2 writing. Middle East Technical University English Language Teaching Undergraduate Students Conference on 5-6 June 2016, 16-25. https://dergipark.org.tr/en/download/article-file/349051

Goo, J., \& Takeuchi, T. (2021). Corrective feedback and affect. In The Cambridge Handbook of Corrective Feedback in Second Language Learning and Teaching (pp. 713-732). Cambridge https://doi.org/10.1017/9781108589789.034

University Press.

Harris, L. R., Brown, G. T. L., \& Harnett, J. A. (2014). Understanding classroom feedback practices: A study of New Zealand student experiences, perceptions, and emotional responses. Educational Assessment, Evaluation and Accountability, 26(2), 107-133. https://doi.org/10.1007/s11092-013-9187-5

Hughes, A. (2003). Testing for Language Teachers (S. Michael (ed.)). Press Syndicate.

Hyland, K. (2013). Faculty feedback: perceptions and practices in L2 disciplinary writing. Journal of Second Language Writing, 22(3), 240-253. https://doi.org/10.1016/j.jslw.2013.03.003

Hyland, K., \& Hyland, F. (2006). Feedback on second language students' writing. Language Teaching, 39(2), 83-101. https://doi.org/10.1017/S0261444806003399

Irwin, B. (2017). Written corrective feedback: student preferences and teacher feedback practices. IAFOR Journal of Language Learning, 3(2), 35-58. http://iafor.org/archives/journals/iafor-journal-of-languagelearning/10.22492.ij11.3.2.02.pdf

Jayathilake, C. (2013). Correcting errors: the relative efficacy of different forms of error feedback in second language writing. English Review: Journal of English Education, 1(2), 1-12. http://journal.uniku.ac.id/index.php/ERJEE

Joshi, A., Kale, S., Chandel, S., \& Pal, D. (2015). Likert scale: explored and explained. British Journal of Applied Science \& Technology, 7, 396-403. https://doi.org/10.9734/BJAST/2015/14975

Kennedy, S. (2010). Corrective feedback for learners of varied proficiency levels: a teacher's choices. TESL Canada Journal, 27(2), 31. https://doi.org/10.18806/tesl.v27i2.1054

Li, S. (2010). The Effectiveness of corrective feedback in SLA: a meta-analysis. Language Learning, 60(2), 309-365. https://doi.org/10.1111/j.14679922.2010.00561.x

Lyster, R., \& Saito, K. (2010). Oral feedback in classroom SLA: A meta-analysis. In Studies in Second Language Acquisition (Vol. 32, Issue 2). Kean University. https://doi.org/10.1017/S0272263109990520

Mahfoodh, O. H. A. (2017). "I feel disappointed": EFL university students' emotional responses towards teacher written feedback. Assessing Writing, 31, 53-72. https://doi.org/10.1016/j.asw.2016.07.001

Martínez, J. D. D. (2014). An investigation into how EFL learners emotionally respond to teachers' oral corrective feedback. Colombian Applied Linguistics Journal, 15(2), 265. https://doi.org/10.14483/udistrital.jour.calj.2013.2.a08

Palmer, C., \& Bolderston, A. (2006). A brief introduction to qualitative research. Canadian Journal of Medical Radiation Technology, 37(1), 16-19. https://doi.org/10.1016/s0820-5930(09)60112-2

Pourdana, N., Nour, P., \& Yousefi, F. (2021). Investigating metalinguistic written 
EduLite Journal of English Education, Literature, and Culture

Vol. 6, No. 2, August 2021, pp. 287-299

E-ISSN: 2528-4479, P-ISSN: 2477-5304

http://jurnal.unissula.ac.id/index.php/edulite DOI: http://dx.doi.org/10.30659/e.6.2.287-299

corrective feedback focused on EFL learners' discourse markers accuracy in mobile-mediated context. Asian-Pacific Journal of Second and Foreign Language Education, 6(1). https://doi.org/10.1186/s40862-021-00111-8

Sarsar, F. (2017). Student and instructor responses to emotional motivational feedback messages in an online instructional environment. Turkish Online Journal of Educational Technology, 16(1), 115-127.

Saukah, A., Dewanti, D. M. I., \& Laksmi, E. D. (2017). The effect of coded and noncoded correction feedback on the quality of Indonesian EFL students' writing. Indonesian Journal of Applied Linguistics, 7(2), 247-252. https://doi.org/10.17509/ijal.v7i2.8127

Storch, N. (2010). Critical feedback on written corrective feedback research. International Journal of English Studies, 1O(2), 29. https://doi.org/10.6018/ijes/2010/2/119181

Swain, M. (2013). The inseparability of cognition and emotion in second language learning. Language Teaching, 46(2), 195-207. https://doi.org/10.1017/S0261444811000486

Taufiqulloh; Yuvita; Yuliarto, I. (2016). Utilizing peer and teacher feedback in academic writing class. English Review: Journal of English Education, 4(2), 161. https://doi.org/10.25134/erjee.v4i2.331

Truscott, J. (1996). The case against grammar correction in L2 writing classes. Language Learning, 46(2), 327-369. https://doi.org/10.1111/j.14671770.1996.tb01238.x

Truscott, J. (2007). The effect of error correction on learners' ability to write accurately. Journal of Second Language Writing, 16, 255-272. https://doi.org/10.1016/j.jslw.2007.06.003

Westmacott, A. (2017). Direct vs. Indirect written corrective feedback: student perceptions. $\quad$ ikala, 22(1), 17-32. https://doi.org/10.17533/udea.ikala.v22n01a02

Wibowo, J. A. (2018). Emotional responses of corrective feedback in teacher training class at university level. Scope: Journal of English Language Teaching, 2(01), 48. https://doi.org/10.30998/scope.v2i01.1791

Conflict of Interest Statement: The authors declare that the research was conducted in the absence of any commercial or financial relationships that could be construed as a potential conflict of interest.

Copyright (C) 2021 Bhuana and El Fauziah. This is an open-access article distributed under the terms of the Creative Commons Attribution License (CC BY). The use, distribution or reproduction in other forums is permitted, provided the original author(s) and the copyright owner(s) are credited and that the original publication in this journal is cited, in accordance with accepted academic practice. No use, distribution or reproduction is permitted which does not comply with these terms. 